\title{
La comunidad cardiológica ante la pandemia de COVID-19
}

\author{
The cardiology community in the face of the COVID-19 pandemic
}

\author{
Eduardo Meaney*
}

E

ste suplemento especial de nuestra revista Cardiovascular and Metabolic Science, Órgano Oficial de la Asociación Nacional de Cardiólogos de México (ANCAM) y de las numerosas sociedades y asociaciones afines que componen una especie de fraternidad, ofrece una serie de artículos y revisiones sobre importantes temas cardiometabólicos relacionados con la funesta pandemia de COVID-19, causada por el virus SARS-COVID-2, que ha causado estragos sanitarios y económicos en todo el mundo.

Las directivas de la ANCAM y de la Sociedad Mexicana de Cardiología (SMC) llegaron al acuerdo de que estos materiales fueran publicados en las revistas de ambos agrupamientos, dada la importancia de llevar conceptos claros, basados en hechos científicos y en la evidencia clínica disponible, no sólo a los cardiólogos, sino al resto de la comunidad médico-científica del país. Por ello, aunque nuestra revista desde hace algunos años está escrita exclusivamente en idioma inglés, dado que estos mensajes deben tener la más amplia difusión posible en el ámbito nacional y latinoamericano, es que el presente suplemento está publicado en lengua española, excepto uno de los artículos que forman el fascículo.

La sociedad humana se ha enfrentado a enfermedades epidémicas desde su arribo a la faz del planeta. Algunas fueron particularmente letales, como las de la peste en tiempos del emperador Justiniano (a la mitad del primer milenio de nuestra era) y la más grave aún, en el siglo XIV, que mató a uno de cada tres europeos de entonces. Estas catástrofes dejan siempre terribles cicatrices

* Editor en Jefe. de la humanidad. Algunas como la viruela que trajeron los conquistadores españoles, la cual mató a millones de indígenas y facilitó la casi supresión de las culturas originales; sus consecuencias sociopolíticas todavía las estamos padeciendo.

Esta pandemia de COVID-19 no es más letal que las epidemias que en otros tiempos asolaron a la comunidad humana, pero acontece en un mundo, valga decir, «globalizado», donde la movilidad de personas y mercancías es inconmensurablemente mayor que en la época de Gengis Khan. Por ello, es imposible contener la propagación de la enfermedad aislando por tiempos prolongados no sólo a individuos o familias, sino a comarcas o naciones enteras. Por ello, a las valiosas vidas humanas perdidas, se suma la catástrofe económica que ya está flagelando a todo el mundo y cuyas consecuencias todavía no son del todo calculables.

La epidemia nos ha enseñado que hay medidas médico-preventivas realmente útiles, que desafortunadamente no siempre son acatadas por todos, por ignorancia, necedad o tozudez. Dicen que la primera víctima en una guerra es la verdad. Extendiendo este concepto al campo de la epidemiología y la prevención, una de las primeras víctimas de la lucha para contener la epidemia es la verdad sanitaria. En diversos medios, pero en especial en las famosas «redes sociales» se propagan, junto a datos interesantes y verídicos, una sarta de necedades, medias verdades, falsedades histéricas y catastrofistas y bulos («paparruchas» o fake news) que desorientan no sólo a los legos, sino a muchos médicos. Por ello es importante difundir la verdad científica a toda 
la comunidad médica. Muchos de nuestros colegas, junto a enfermeras, enfermeros y personal de laboratorio y apoyo están en la primera línea del combate contra el COVID-19, exponiendo heroicamente la vida para ayudar a las víctimas de esta enfermedad. Pero todos, desde nuestro propio lugar y competencia, podemos ayudar a derrotar a la epidemia. Luchar por la verdad científica en estos tiempos de crisis e histeria colectiva proporciona una gran ayuda al esfuerzo común contra la pandemia. Por esto, hay que agradecer la labor de los autores de estos trabajos que, indudablemente, ayudarán en buena medida a que venzamos a la enfermedad.

iMuchas gracias!

\section{Correspondencia:}

\author{
Eduardo Meaney, MD, PhD \\ Laboratorio de Investigación \\ Integral Cardiometabólica \\ Sección de Estudios de Postgrado \\ e Investigación. \\ Escuela Superior de Medicina, \\ Instituto Politécnico Nacional. \\ E-mail: lalitomini@prodigy.net.mx
}

